\title{
Improving Quality of Services and Customer Satisfaction of Retail in Surabaya by Design of Shopping Map Using Kano Model
}

\author{
Sugijanto ${ }^{1,}$ Budi Prijo Sembodo ${ }^{2}$, I Ketut Surabagiarta ${ }^{3}$ \\ ${ }^{I}$ (Faculty of Economics, University of PGRI Adibuana Surabaya) \\ ${ }_{2}^{2}$ (Faculty of Industrial Engineering, University of PGRI Adibuana Surabaya) \\ ${ }^{2}$ (Faculty of Economics, University of PGRI Adibuana Surabaya)
}

\begin{abstract}
Level of services quality and satisfaction in the search of desired product easily and quickly could make retail customers decided to shopping in modern store continuously. Shopping Map using Kano Model approach are designed to answer the problems that arises when consumers shopping at a retail.Aims to determine the attributes that will be used to draft the Shopping Map application.Data collecting method used was a questionnaire with 200 number of samples consumers. The results of calculations 13 attribute all of which have an average value above scale of 2.5 , it means that all the attributes considered important and will be used in the design of the application. The results of the customer survey tabulation Kano Model customer satisfaction level obtained as much as 2 One-dimensional category attributes and 10 attributes atrractive category and one category attribute Indifferent. IBT contribution value (CSC-positive) a maximum of 0.86 almost reached 1 and negative CSC value most approaching value -1 with value of - 0.52 is attribute number one that desired by the customer is easily installed apps and can be downloaded various brand smartphone. Which means that the influence on dissatisfaction on this attribute very strong if the product features are not fulfilled whereas application has a "thank-you note" do not cause dissatisfaction if not fulfilled has caused value of -0.19 approaching 0 .
\end{abstract}

Keywords: service quality, customer satisfaction, shopping mapDesign,KanoModel, CSC.

\section{Introduction}

A modern retail or can be called the modern market is a form of change from traditional markets that are affected by changes in people's lifestyles and economic development as well as technology. Beside that also the existence of modern stores or retail inseparable from the support public shopping taste for comfortable acquired, neat and well-organized goods at prices that are already placed on each product so it doesn't need bargain process compared to traditional markets, it makes people decided to shop in modern stores. Nowadays the growth of retail / modern shops very rapidly, retail market in Indonesia continues to grow according data which was released by AT Kearney, Indonesia Indonesia is ranked 12th in the world in the Global Retail Development Index (GRDI) 2015. This is the highest retail growth rate ever reached Indonesia in the index since 2001, also AT Karney said Indonesia ranked assisted economic outlook is positive, Indonesia's GDP growth is expected to rebound after hitting the lowest number in five years at the beginning of 2015, and exceeded other regional markets forward [1]. Surabaya is the second largest city in Indonesia. Prospects for the development of retail businesses and shopping centers assessed getting better when seen from Indonesia's economic growth reached an average of 6\% per year as domestic consumption reached $54.56 \%$ of the Gross Domestic Product (GDP). The amount of domestic consumption was driven by the large number of Indonesian population of 250 million, with the structure of the population aged under 39 years to reach $60 \%$ as well as the middle class population reached 45 million in 2014, in 2016 began apply the Asean Economic Community (AEC) estimated retail growth in Indonesia will grow more rapidly again [2].

Shopping goods or products in a retail shopping center that faced by consumers is the difficulty when searching a desired product that can be purchased easily and quickly, also the change of the layout (Layout) display rack and displacement of products by service providers or manufacturers. This was done in order to obtain an atmosphere or an exciting new look, a change like this would not be known to customers as a result of customers difficulty in finding the desired product easily and quickly. The level of service quality and satisfaction in the search for a desired product easily and quickly create retail customers drop his choice to shop in modern stores. Shopping Map with Kano model approach will be designed to answer the problems that arise when consumers shop in a retail shopping center in Surabaya. 


\section{Objective}

Behavior or habits of retail customersassociated with the technologyis very interesting to study. Therefore, in this research aims to:

a. Determine the attributes that will be implemented in software through the draft questionnaire in Kano models and identify the results of questionnaires.

b. CSC (Consumer Satisfaction Coefficient) value is calculated to determine the value of an attribute of the application to be designed

\section{Theory}

Customer assessment of the quality of a service that felt based on what they describe within their minds. Customer needs factors determine the quality of a service where the consumer perception of the service received (perceived service) in the form of actual services expected / desired (expected service) created a customer satisfaction.Definition of the customer is the person who does not depend on us, but we who depend on them[3]. By fulfilling the needs of customers for a product that is desired and easily search on a shelves in order to obtain the level of customer satisfaction.Product quality, service quality, customer satisfaction and rebuying interest in the supermarket is quite good but there are still some things that need to be improved again as the preparation of the product in the display rack that is attractive and easy to find, the ability to deal with customers so that consumers feel satisfied and affect the re-buying interest [4]. Similar with research is done,Layout of store has positive impact on consumer purchasing decisions. $13.39 \%$ contributed in consideration making purchasing decisions and the remaining $86.61 \%$ influenced by other factors not examined in this research[5].

There are five forms of the quality of a service among others: 1)Tangibles(physical evidence)2)Reliability(Reliability)3)Responsiveness(responsiveness) is an ability to assist and provide fast service and right to the consumer, through the delivery of clear information. Leaving consumers to wait without any obvious reason causing a negative perception in service quality. 4)Assurance(guarantees and assurances) and 5)Empathywhere a company is expected to have the understanding and knowledge of the customer, understanding the specific needs of consumers, and has the operating time that is comfortable for the consumer [6].That customer satisfaction is a post-purchase evaluation where selected alternatives at least provide the results (outcomes) equal or exceed customer expectations [7]. Meanwhile, Consumer satisfaction is the most crucial concepts in the thinking and consumer research. In theory, consumers are satisfied with the product, service or brand, is likely to continue to buy it and tell others about the experiences pleasant feeling [8].

Many methods in measuring customer satisfaction, the one used in this research to measure customer satisfaction with the Kano Model. Until now, Kano model is a model that aims to categorize the attributes of a product or service based on how well the products / services capable of satisfying the needs of customers. The results are mostly friendly and quick service attributes, product taste and price (Must be) very meaningful for the level of customer satisfaction. For websites and menus are presented is not very meaningful to the consumer will be negative consequences if you do excessive [9].From the calculation Customer Satisfaction Indexobtained CSI value is equal to $61.36 \%$ that indicate costumer saticfation level fulfill the service PT. PLN (Persero) region Lenteng Court is quite satisfied [10], andFrom calculations that have been done before, there are 17 attributes that need to be improved (Action) and there are 10 attributes that need attention to be retained by the company (Hold) [11].

\section{Kano Model.}

In his method, Kano model (figure 1) divided into six categories, yaitu must be, onedimensional, attractive, indifferent, reserve, danquestionable.[12]

1. Must beis the category that should be applied in a product. If the attributes that belong to the 'must be' category applied, then customer satisfaction will increase customer satisfaction. But will not rise much above neutral even though the performance of these attributes high.

2. One dimensionalis the category that if the attribute is more applied, then customer satisfaction will also be increase.The customer satisfaction is linearly related to the performance attributes, so that the high performance attributes that will lead to high customer satisfaction as well.

3. 3)attractiveis a category if implemented, customer satisfaction will also increase, but a decrease in performance attributes will not cause a decrease in the level of satisfaction in other words, the existing attributes of this type are not required to be applied.

4. Indifferent is the category that showed that customer satisfaction levels do not affect the results of performance attributes.

5. Reserve indicates that the level of customer satisfaction is inversely proportional to the results of performance attributes. 


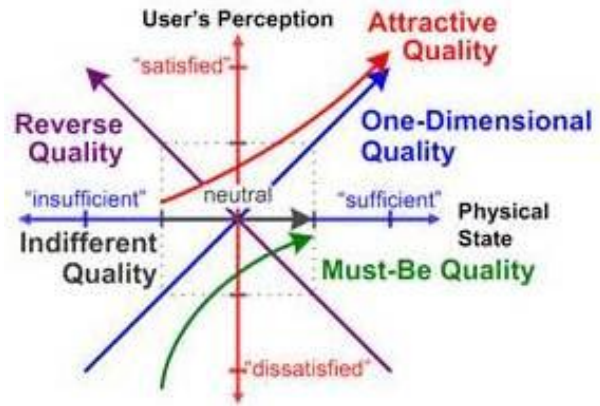

Figure1:Kano Model

6)Questionableindicates that the answers of the respondents are not clear or less in accordance with any questions. In other words, there is a contradiction in the answers to the customer so that the customer satisfaction can not be defined.

To perform the analysis using the Kano Model, the steps are as follows:

1. Identify and define the attributes that need to be put into the questionnaire and which did not need to be put into the questionnaire.

2. Make a list of questionnaires based on the specified attributes with each attribute 2 questions (functional/positive and dysfunctional/negative).

3. Identify the deployment of the results of questionnaires to thetable Kano.

4. Inputting into the Survey Tabulation to meet all the attributes Must be, One dimensional,Attractive, Reverse , IndefferentandQuestionable.

5. Determining the grade for each attribute using Blauth's formula, as follows:

- If (one dimensional + attractive + must be $)>($ indifferent + reverse + questionable $)$ hence grade obtained from the maximum of (one dimensional, attractive, must be).

- If (one dimensional + attractive + must be $)<($ indifferent + reverse + questionable $)$ hence grade obtained from the maximum of (indifferent,reverse, questionable).

Table 1 :Kano Evaluation

\begin{tabular}{|c|c|c|c|c|c|c|}
\hline \multirow{2}{*}{\multicolumn{2}{|c|}{ Custamer Requirements }} & \multicolumn{5}{|c|}{ Disfungsional/negattif } \\
\hline & & \multirow{2}{*}{$\frac{\text { Like }}{Q}$} & \multirow{2}{*}{ Must be } & \multirow{2}{*}{$\frac{\text { Neutral }}{A}$} & \multirow{2}{*}{$\frac{\text { Live With }}{A}$} & \multirow{2}{*}{$\frac{\text { Distike }}{Q}$} \\
\hline$\equiv$ & Wike/ & & & & & \\
\hline$\ddot{z}$ & Must be & R. & t & 1 & t & M \\
\hline $\bar{E}$ & Neutralf & $R$ & 1 & 1 & $t$ & $M$ \\
\hline$\vec{B}$ & Live With & R & 1 & 1 & 1 & M \\
\hline$E$ & Dis Like & $R$ & $R$ & $R$ & $R$ & $Q$ \\
\hline
\end{tabular}

source: Walden, 1993

\section{Consumer Satisfaction Coefficient (CSC)}

CSC evaluation is a method that aims to determine the level of user satisfaction in each attribute, the value of an attribute of the application to be designed if these attributes affect user satisfaction if developed, or cause user dissatisfaction if developed.With the value of CSC it will be known which attributes can boost user satisfaction of shopping map applications. Moreover the value of CSC also be taken into consideration in the decision whether these attributes will be applied or not[13].

Accordingfor calculating the value of CSC uses several ways, is by using a specific formula to find IBT and IWTvalue:

Satisfaction: $\quad \frac{A+O}{A+M+O+I} \quad \ldots \ldots \ldots . . .(1)$
Dissatisfaction: $\quad-\frac{O+M}{(A+O+M+I)} \ldots \ldots \ldots . .(2)$

Description :

A $\quad$ :number of attributes attractive category

$\mathrm{O} \quad$ :number of attributes that are categorized as one dimensional

M :number of attributes must-be category

I : number of attributesindifferentcategory 
IBT value (CSC-positive) has a value ranges from 0 to 1 , which means the closer the value 1 higher influence on customer satisfaction, approaches 0 indicates that there is very little effect.At the same time also take into consideration IWT (CSC-negative),minus sign placed in front of CSC- negativeindicate costumer dissaticfaction which means has negative impact to costumer saticfation if this product quality doesn't fulfilled. If approach -1,influence on the customer dissatisfaction is very strong if the analyzed product features are not met. While the value of approximately 0 indicates that this feature does not cause dissatisfaction if not met.

\section{Methods}

The population in this research is the object where the observations were made by researchers is the consumer or customer transactions in a retail shopping area Giant Extra Diponegoro Surabaya, determining the number of samples taken in this study conducted [14],suggest minimum number of samples to 100 samples for descriptive research; 50 samples for correlational research; 30 samples in each group to research eksperimendan 30 or 15 samples per group for a causal-comparative research,based on that the number of samples used 200 samples with sampling techniques such as accidental sampling.

\subsection{Characteristic of Responden}

\section{Result And Discussion}

Distribution characteristics of respondents based on the processed data to the 200 people who responded to the questionnaire obtained as follows:illustrates the number of respondents male and female, where as many as 133 women (67\%) have a tendency to like to shop or buy a product to meet the needs of their own households.Seen from the kind of work the respondent is Employee / private sector employees as many as 63 people (31.5\%); Public Servants 35 (17.5\%); Self-employed $36(18 \%)$ and a majority of $66(33 \%)$ of respondents are others (housewives or students). Many types of products purchased by respondents when shopping is 73 respondents $(36 \%)$ bought about 1 to 5 types of products it is because retail Giant Extra Diponegoro is near settlements or serving customers with middle and lower economic, then 6 to 10 kinds of products made by 46 respondents $(46 \%)$ and 44 respondents $(22 \%)$ to buy 11 to 15 types of products and the remaining 37 respondents $(19 \%)$ are buying more than 15 kinds of products.Shopping time is coming back to buy a product, from the results of the questionnaire obtained a majority of 107 (53.5\%) of respondents shopped once a month to come back to shop and $18(9 \%)$ of the respondents spent more than two months to come back to shop.

\subsection{Result of Attribute Determination Questionnaire}

In this research, there are 13 attributes included in the questionnaire and distributed to the respondents as many as 200 according to the research needs. From the results obtained will be determined attributes that are considered important by respondents and used in the calculation Kano model and used to create the application design while the attributes that are not considered important by the respondents will be taken into consideration in making the application design. From the calculation of the questionnaire determination of attributes, attributes considered important has an average value above 2.5 and attributes that are considered not-important with average value is below or equal 2.5 from middle value from scale 2 and 3 the determination of attributes. When the results from all the attributes considered important, then assessment on the attribute value is less than 3.0 (scale 3 determination attribute) be taken into consideration if it can be applied or not be applied in the application design later.The following the results of calculation of attributes can be seen in Table 2 . The average value of all the attributes has an average value above the scale of 2.5 means that the attributes of attributes that will be used in the calculation Kano model, because all the attributes considered important then the next assessment is taken into consideration if it can be applied or not be applied in the application design later with attribute value is less than 3.0 .

Table2:Results Determination of attributes

\begin{tabular}{clc}
\hline Number & \multicolumn{1}{c}{ Attribute Name } & $\begin{array}{c}\text { Avera } \\
g e\end{array}$ \\
\hline 1 & $\begin{array}{l}\text { Application is easy to install and download a variety of smartphone } \\
3,62\end{array}$ \\
2 & brand & \\
2 & Application can be easily operated by all users of smartphone & 3,58 \\
3 & Image or animation in each view & 3,11 \\
4 & Has Images can be expanded and minimized & 3,25 \\
5 & There is anexplanation of each feature in the opening display & 3,52 \\
6 & Has a searchfeature more than one product and its price & 3,18 \\
7 & Has a searchfeature more than one product and its price & 3,51 \\
8 & There is a folder for storing alist of products selected & 3,12 \\
9 & Has a feature calculator manual & 3,21 \\
10 & There is map feature that show the location to where the desired & 3,58 \\
& products quickly & \\
11 & Has Next dan Previous feature in each view & 3,22 \\
12 & The application has "thank-you" note & 2,82 \\
13 & The application has a message from a customer for improvements & 3,09 \\
\hline
\end{tabular}


Only one attribute-value (table 3 ) below the average value of 3.0 is the closing view applications in the form of gratitude and these attributes can be applied because it is only as a thank you and not so influential.

Table3:Attribute with average value below 3,0

\begin{tabular}{ccc}
\hline Number & Attribute Name & Average \\
\hline 12 & The application has "thank-you" note & 2,82 \\
\hline
\end{tabular}

\subsection{Result of Kano Model Questionnaire}

To obtain a grade each attribute (table 4) of the respondents have been processed in accordance with the provisions of the evaluation table based Blauth's formula as follows:

Table4: Tabulation of the customer survey.

\begin{tabular}{cccccccccc}
\hline Atribute & $\mathrm{O}$ & $\mathrm{A}$ & $\mathrm{M}$ & $\mathrm{I}$ & $\mathrm{R}$ & $\mathrm{Q}$ & $\mathrm{A}+\mathrm{M}+\mathrm{O}$ & $\mathrm{I}+\mathrm{R}+\mathrm{Q}$ & Category \\
\hline 1 & 89 & 73 & 8 & 18 & 1 & 11 & 170 & 30 & $\mathrm{O}$ \\
2 & 88 & 65 & 8 & 32 & 1 & 6 & 161 & 39 & $\mathrm{O}$ \\
3 & 31 & 58 & 13 & 85 & 11 & 2 & 102 & 98 & $\mathrm{~A}$ \\
4 & 43 & 66 & 10 & 76 & 3 & 2 & 119 & 81 & $\mathrm{~A}$ \\
5 & 60 & 72 & 14 & 46 & 3 & 5 & 146 & 54 & $\mathrm{~A}$ \\
6 & 30 & 61 & 26 & 59 & 16 & 8 & 117 & 83 & $\mathrm{~A}$ \\
7 & 59 & 80 & 15 & 37 & 7 & 2 & 154 & 46 & $\mathrm{~A}$ \\
8 & 35 & 69 & 15 & 70 & 6 & 5 & 119 & 81 & $\mathrm{~A}$ \\
9 & 34 & 69 & 18 & 71 & 7 & 1 & 121 & 79 & $\mathrm{~A}$ \\
10 & 63 & 84 & 11 & 28 & 6 & 8 & 158 & 42 & $\mathrm{~A}$ \\
11 & 34 & 69 & 17 & 71 & 5 & 4 & 120 & 80 & $\mathrm{~A}$ \\
12 & 23 & 48 & 13 & 105 & 8 & 3 & 84 & 116 & 1 \\
13 & 36 & 68 & 15 & 71 & 6 & 4 & 119 & 81 & $\mathrm{~A}$ \\
\hline
\end{tabular}

\subsection{Consumer Satisfaction Coefficient (CSC) Evaluation}

CSC-coefficient is an indication of how powerful product features can affect customer satisfaction or dissatisfaction, CSC values can also be taken into consideration in the decision whether these attributes will be applied or not.By using the formula IBT (CSC-positive) and IWT(CSC- negative), in Table 5 known The highest value of the contribution CSC-positive is 0.86 approach to 1 is the attribute number one desired by the customer is an application is easily installed and downloaded various smartphone brand, which means the higher the effect on customer satisfaction if is not fulfilled, then followed by the attribute number 2 is an application easily operated by all users and attribute number 10 is a map feature that can show location of desired product quickly. Meanwhile the value of CSC-negativeclosest -1 is attribute number one with value- 0.52 is also wanted by the customer that is easily installed an application and downloaded various smartphone brand, which means the effect of the very strong dissatisfaction atributini if the product features fulfilled. Attribute number 12 does not cause dissatisfaction if not fulfilled because has value -0.19 approaching 0 , so does CSC-positive value approach 0 indicates that there is very little influence when these attributes are applied in the application.

Table5:CSC Evaluation

\begin{tabular}{|l|l|l|l|l|l|l|}
\hline Atribut & O & A & M & I & Better & Worse \\
\hline 1 & 89 & 73 & 8 & 18 & $\mathbf{0 , 8 6}$ & $\mathbf{- 0 , 5 2}$ \\
\hline 2 & 88 & 65 & 8 & 32 & 0,79 & $-0,50$ \\
\hline 3 & 31 & 58 & 13 & 85 & 0,48 & $-0,24$ \\
\hline 4 & 43 & 66 & 10 & 76 & 0,56 & $-0,27$ \\
\hline 5 & 60 & 72 & 14 & 46 & 0,69 & $-0,39$ \\
\hline 6 & 30 & 61 & 26 & 59 & 0,52 & $-0,32$ \\
\hline 7 & 59 & 80 & 15 & 37 & 0,73 & $-0,39$ \\
\hline 8 & 35 & 69 & 15 & 70 & 0,55 & $-0,26$ \\
\hline 9 & 34 & 69 & 18 & 71 & 0,54 & $-0,27$ \\
\hline 10 & 63 & 84 & 11 & 28 & 0,79 & $-0,40$ \\
\hline 11 & 34 & 69 & 17 & 71 & 0,54 & $-0,27$ \\
\hline 12 & 23 & 48 & 13 & 105 & 0,38 & $-0,19$ \\
\hline 13 & 36 & 68 & 15 & 71 & 0,55 & $-0,27$ \\
\hline \hline
\end{tabular}

\section{Conclution}

The results of calculation of 13 attributes all of which have an average value above the scale of 2.5 means that all the attributes considered important and will be used in the calculation Kano model and application design. Only one attribute-value below the average value of 3.0 is the closing view applications in the form of gratitude and these attributes can be applied because it is only as a thank you and not so influential. 
The results of the customer survey tabulation Kano model, levels of customer satisfaction obtained as much as 2 attribute One-dimensional category where the level of customer satisfaction is linearly related to the performance attributes, so the high performance attributes that will lead to high customer satisfaction and 10 are also categorized Atrractive attribute if the attribute is applied it will also increase customer satisfaction, but the decrease performance attributes will not cause a decrease in the level of satisfaction as well as one attribute Indifferent category which show that the level of customer satisfaction does not affect the results of performance attributes.The highest value of the contribution CSC-positive is 0.86 approach to 1 is the attribute number one desired by the customer is an application is easily installed and downloaded various smartphone brand, which means the higher the effect on customer satisfaction if is not fulfilled, then followed by the attribute number 2 is an application easily operated by all users and attribute number 10 is a map feature that can show location of desired product quickly. The value of CSC-negative closest -1 is attribute number one with value -0.52 is also wanted by the customer that is easily installed an application and downloaded various smartphone brand, which means the effect of the very strong dissatisfaction atributini if the product features fulfilled. Attribute number 12 does not cause dissatisfaction if not fulfilled because has value -0.19 approaching 0 .

\section{Acknowledgements}

I would like to thank the various agencies for their contributions and technical support are valuable in this study include: MINISTRY OF RESEARCH, TECHNOLOGY, AND STRENGTHENING THE GENERAL DIRECTORATE OF HIGHER EDUCATION RESEARCH AND DEVELOPMENT;retail leaders and staf Giant Extra Diponegoro Surabaya.

\section{Reference}

[1]. B.C. Nursyifani, 2016,Memanfaatkan Momentum Bisnis Ritel, http://koran.bisnis.com/read/20160608/245/555516, accessed at 2016June $6^{\text {th }}$.

[2]. S. Deny, 2014, 765 Ribu Gerai Ritel Menjamur di Indonesia,http://bisnis.liputan6.com, accessed at 2015 june $10^{\text {th }}$

[3]. T. Wijaya, 2011, ManajemenKualitasJasa, edisipertama, cetakanpertama, Penerbit :Ikdeks, Jakarta

[4]. B. SaidaniandS.Arifin, PengaruhKulaitasProdukdanKualitasLayananTerhadapKepuasanKonsumendanMinatBeliPada Ranch Market, JurnalRisetManajemenSains Indonesia (JRMSI), 2012,Vol. 3, No. 1.

[5]. D.Noviyantietc,Pengaruh Layout TokoTerhadapKeputusanPembelianKonsumen (StudiKasusPadaKonsumenCentermartBengkalis, TugasAkhir, AdministrasiBisnisPoliteknikNegeriBengkalis, 2012

[6]. Lupiyoadi, RambatandHamdani, 2006, ManajemenPemasaranJasa, edisikedua, Penerbit :SalembaEmpat,Jakarta

[7]. Tjiptono, F., Chandra, Gregoriousand Adriana, Dedi, 2008, Pemasaran Strategic, Yogyakarta: Andi Offset.

[8]. J.Paul Peter and Jerry C. Olson, 2014, PerilakuKonsumendanStrategiPemasaran; Edisi 9, Buku 2, SalembaEmpat, Jakarta

[9]. H.Tannadyand R. Mulyadi, PengukuranKepuasanPelangganMenggunakanMetode Kano (StudiKasus: RestauranCepatSaji McDonald), 2014, SNTI IV-2014 ISSN: 2355-925X, UniversitasTrisakti, 2014, Volume 1 Nomor 1.

[10]. Tiena, G.AmranandP.Ekadeputra,PengukuranKepuasanPelangganMenggunakanMetode Kano dan Root Cause Analysis (StudiKasus PLN Tangerang), JurnalTeknik IndustriISSN:1411-6340, UniversitasTrisakti, 2012, Volume 2 Nomor 2.

[11]. M.Yolaand D. Budianto, AnalisisKepuasaanKonsumenTerhadapKualitasPelayanandanHargaProdukPada Supermarket DenganMenggunakanMetode Importance PerformaceAnaysis (IPA), JurnalOptimasiSistemIndustri (JOSI), 2013, Vol. 12 No.12, 301-309.

[12]. A.C. Dewantari, A. Kurniawati and M.Iqbal, Outbound Tour Service Quality Improvement at PT X Using Integration of Servqual, Kano Model, and QFD, INTEGRA JOURNAL, VOL. 2, NO. 1, JUNI 2012: 1-18

[13]. D. Wijaya, E.F. Sri Maryani and NurHidayat, Determination Of Characteristic Product As Consideration In Tempe Chips Product Development Planning (Study Case in Industry Tempe Chips"ABADI" Malang), TeknologiIndustriPertanian FTP-UB, 2012, http://nurhidayat.lecture.ub.ac.id/ accessed at 2016 June $^{\text {th }}$.

[14]. Fraenkel, Jack R., 2012, How to Design and Evaluate Research in Education, Eighth Ed., Copyright @ 2012 by The McGraw-Hill Companies, New York, NY 10020 